\title{
L-Alanyl-L-Tyrosine As A Tyrosine Source During Total Parenteral Nutrition. Infusion at 0.5 and 2 mmoles/kg/day in Adult Rats
}

\author{
TAHIA T. DAABEES (46) and LEWIS D. STEGINK (48)
}

Departments of Pediatrics \& Biochemistry, University of Iowa College of Medicine, Iowa City, Iowa USA

\begin{abstract}
Summary
Tyrosine peptides, such as L-alanyl-L-tyrosine, have excellent solubility and are potential sources of iv tyrosine. Infusion of $L$ alanyl-L-U- ${ }^{14} \mathrm{C}$-tyrosine as part of a total parenteral nutrition regimen in the rat at a level of $0.5 \mathrm{mmole} / \mathrm{kg} / \mathrm{day}$ resulted in rapid labeling of tissue tyrosine pools, production of ${ }^{14} \mathrm{CO}_{2}$, incorporation of ${ }^{14} \mathrm{C}$-labeled tyrosine into protein, and minimal urinary losses $(7.7 \%)$. Plasma tyrosine levels, however, remained at fasting. Infusion of L-alanyl-L-tyrosine at $2 \mathrm{mmole} / \mathrm{kg} / \mathrm{day}$ increased plasma tyrosine above fasting levels and maintained tissue tyrosine at levels seen in orally fed control animals without increasing the percent lost in urine $(5.5 \%)$. Rapid utilization of $L$-alanyl-L-tyrosine was noted at both infusion levels with no accumulation of peptide noted in plasma. Plasma and tissue free tyrosine pools were rapidly labeled, as was tissue protein. Radioactivity incorporated in tissue protein was shown to be tyrosine after acid hyrolysis.
\end{abstract}

\section{Speculation}

Tyrosine content of parenteral solutions is limited by poor tyrosine solubility. Tyrosine peptides are soluble and are well utilized during iv feeding of adult rats. This suggests that tyrosine peptides are a reasonable source for supplying the tyrosine requirements of iv fed infants.

Cystine and tyrosine are essential amino acids for some premature infants $(19,33,41)$. Both amino acids have limited solubility, and cannot be added to total parenteral nutrition solutions in quantities sufficient to meet the infants requirements. The absence of these amino acids results in depresed cystine and tyrosine levels in infants infused with such solutions $(30,35,38)$.

Soluble peptides of cystine and tyrosine are potential sources for adding these amino acids to parenteral solutions (36). Although some studies suggested that peptide nitrogen is not well utilized during parenteral nutrition $(7-11,13,16,21,23)$, peptide utilization is nearly equal to that of infused amino acids once products of the Maillard reaction are eliminated from the parenteral solutions $(11,36,39)$. Preliminary studies (36) indicated good utilization of L-alanyl-L-tyrosine as a tyrosine source in adult rats when administered at $0.5 \mathrm{mmole} / \mathrm{kg} /$ day either by ip injection or as part of a total parenteral nutrition regimen. The peptide was utilized as a tyrosine source for protein synthesis, as evidenced by incorporation of tyrosine into tissue protein, and for energy production, as evidenced by rapid conversion to carbon dioxide. However, plasma tyrosine levels remained in the fasting range and $7.7 \%$ of peptide tyrosine was lost in the urine. The present study compares infusion of L-alanyl-L-tyrosine at 0.5 and $2.0 \mathrm{mmole} / \mathrm{kg} / \mathrm{day}$ as part of a parenteral nutrition regimen in adult rats to determine whether: 1) good utilization occurs at higher peptide infusion levels; 2) plasma tyrosine levels can be increased above fasting levels; and 3) urinary losses of tyrosine will increase at higher infusion levels.

\section{MATERIALS AND METHODS}

L-Alanyl-L-tyrosine and L-alanyl-L-U- ${ }^{14} \mathrm{C}$-tyrosine were purchased from Vega-Fox Biochemicals, Tucson, Az. The purity was confirmed by amino acid analysis before and after acid hydrolysis.

Healthy male Sprague-Dawley rats, weighing 400-500 g were used for all experiments. The method of Popovic and Popovic (31) was used for the cannulation of the animals. This method allows work on unanaesthetized animals and simultaneous sampling of arterial blood while the nutrient solution is infused into the venous circulation. The catheters were placed under ether anesthesia, and the animals allowed to recover from the operative procedure for a 2-day period.

After recovery, the animals were placed in restraining metabolism cages and alimented parenterally using the parenteral nutrition solution described by Steiger et al (40) for a 24-hr period. The base solution was prepared by adding sterile $50 \%$ dextrose solution to an $8.5 \%$ solution of crystalline amino acids (FreAmine, McGaw Laboratories, Glendale, CA) 2:1, to yield the $33 \%$ glucose-2.8\% amino acid solution infused. This solution does not contain tyrosine. Electrolytes and vitamins were added to the recommendation of Steiger et al. (40). The solution was infused into the venous cannula at a rate of $50-55 \mathrm{ml} / \mathrm{day}$ by pump (Extra-corporal Medical Specialties, Bridgeport, PA). Total daily energy intake was between 73 to $80 \mathrm{kcal}$, sufficient to provide maintenance requirements of adult rats $(40,44)$.

Four groups of five animals each were studied. The first group was infused with the parenteral solution without added peptide. The second and third groups of animals were infused with the same parenteral alimentation solution to which L-alanyl-L-tyrosine was added at levels providing either 0.5 or 2.0 mmoles of peptide/ $\mathrm{kg}$ body wt $/ 24 \mathrm{hr}$ infusion. Sufficient L-alanyl-L-U- ${ }^{\mathrm{I}}{ }^{4} \mathrm{C}$-tyrosine was added so that $15 \mu \mathrm{Ci}$ was infused per $24 \mathrm{hr}$ in each case. The fourth group of rats was fed with standard rat chow after catheter placement. The infused solutions were sterilized by passage through a $0.22 \mu$ membrane filter (Millipore Corporation, Bedford, MA) before infusion.

Sequential 4-hr urine samples were collected in iced graduate cylinders during the infusion, and deproteinized immediately with sulfosalicylic acid (15). Blood samples $(0.5 \mathrm{ml})$ were drawn from the arterial cannula at 0,6 , and $24 \mathrm{hr}$, heparinized, and centrifuged to separate plasma and erythrocytes. Plasma was immediately deproteinized by addition of an equal volume of $8 \%$ sulfosalicylic acid. The precipitated protein was removed by centrifugation (Airfuge, Beckman Instruments, Palo Alto, CA). Erythrocytes were prepared for amino acid analysis, after removal of the white cell layer, by hemolyzing one volume of packed cells with three volumes of cold thiodiglycol solution $(0.5 \% \mathrm{v} / \mathrm{v})$, and then deproteinized by the addition of an equal volume of $8 \%$ sulfosalicylic acid. The precipitated protein was removed by centrifugation. All physiologic fluid samples were either analyzed immediately, or stored at $-70^{\circ} \mathrm{C}$ until analysis to prevent loss of glutamine and cystine $(14,29)$.

Amino acid analyses were carried out using Beckman $121 \mathrm{M}$ 
amino acid analyzers (Beckman Instruments, Palo Alto, CA). Simultaneous radioactivity-amino acid analyses were carried out as described by Stegink (37).

At the end of the parenteral infusion, the animals were lightly anesthetized with ether, and the tissue samples (liver, kidney, muscle, intestine, brain, stomach, heart, lung, spleen) quickly excised, blotted, and weighed. The remaining carcass was skinned. One $\mathrm{g}$ portions of each tissue were homogenized in $10 \mathrm{ml}$ of $5 \%$ sulfosalicylic acid for $3 \mathrm{~min}$ in a Virtis microhomogenizer. The precipitated protein was removed by centrifugation at $20,000 \times \mathrm{g}$ for $15 \mathrm{~min}$ at $4^{\circ} \mathrm{C}$ in a refrigerated centrifuge (International B20 ), and aliquotes for the supernatant solution were assayed for radioactivity and amino acid distribution as described by Stegink (37). The entire skin and remaining carcass were similarly treated.

The total radioactivity present in plasma, urine, tissue, and carcass homogenates was determined by adding aliquots of the homogenate to $10 \mathrm{ml}$ of scintillation fluid (6). The values were quench corrected. Background noise was eliminated by counting an appropriate portion of control urine, plasma, or tissue homogenates. The quantity of radioactivity present in protein fractions of the samples was determined by dissolving a specific weight of precipitated protein in hyamine hydroxide (Packard Instrument Co., Downers Grove, IL) followed by digestion for $48 \mathrm{hr}$ at $37^{\circ} \mathrm{C}$ before counting.

The distribution of radioactivity between the various amino acids in the protein fraction was determined after acid hydrolysis. The precipitated protein was collected by centrifugation, suspended in $5 \mathrm{ml}$ of $3.5 \%$ sulfosalicylic acid, and the protein again collected by centrifugation. The supernatant solution was discarded and the procedure repeated three times to remove any traces of free tyrosine or alanyl-tyrosine. The precipitated protein was then dissolved in $6 \mathrm{~N} \mathrm{HCl}$ in a hydrolysis tube. The tube was evacuated using a vacuum pump and then flushed with dry, oxygen-free nitrogen gas. After repeating the process three times, the tube was sealed and the protein hydrolyzed for $22 \mathrm{hr}$ at $115^{\circ}$ C. The hydrolysate was lyophilized to dryness, the residue dissolved in 5\% sulfosalicylic acid, and then subjected to the simultaneous radioactivity - amino acid analysis procedure (37). In those animals studied for the rate of carbon dioxide production, the animals were placed in a glass metabolism chamber, and the labeled carbon dioxide collected as described by Palese and Tephly (27).

Statistical analysis of the data was carried out using the paired $t$ test and the Student's $c$ test (34).

\section{RESULTS}

Plasma amino acid levels, both before parenteral alimentation and after $24 \mathrm{hr}$ infusion, are shown in Table 1. In general, plasma levels of those amino acids present in the parenteral solution increased from the fasting levels noted in preinfusion samples, to levels considered postprandial in samples taken after $24 \mathrm{hr}$ infusion. Plasma levels of those amino acids not present in the parenteral solution remained at fasting levels or decreased. The addition of L-alanyl-L-tyrosine to the parenteral solution at a level of $0.5 \mathrm{mmole} / \mathrm{kg} / \mathrm{day}$ did not affect plasma tyrosine levels, which remained at preinfusion values, and were similar to those noted in rats infused with the tyrosine-free parenteral solution without added peptide. Animals infused with L-alanyl-L-tyrosine at 2 $\mathrm{mmole} / \mathrm{kg} /$ day had increased plasma tyrosine levels. Plasma tyrosine reached $9.2 \pm 2.1 \mu$ moles/dl (mean \pm SD) $6 \mathrm{hr}$ into the infusion, stabilized by $24 \mathrm{hr}$ at $13.0 \pm 2.13 \mu \mathrm{moles} / \mathrm{dl}$, and did not increase further after $48 \mathrm{hr}$ infusion at this level.

Plasma alanine levels in animals infused with $\mathrm{L}$-alanyl-I-tyrosine at $0.5 \mathrm{mmole} / \mathrm{kg} /$ day were similar to those noted in animals infused without peptide, but were significantly higher $(P=0.001)$ in animals infused with $\mathrm{L}$-alanyl-L-tyrosine at $2 \mathrm{mmole} / \mathrm{kg} / \mathrm{day}$.

The infusion of radioactivity-labeled peptide (I-alanyl-L-U- ${ }^{14} \mathrm{C}$ tyrosine) made it possible to evaluate utilization of the peptide bound tyrosine for both energy production $\left(\mathrm{CO}_{2}\right)$ and protein synthesis. The data in Table 2 demonstrate peptide utilization during total parenteral alimentation at both infusion levels. The distribution of infused label among body tissues and fluids was similar at both infusion levels, although animals infused at 2 mmole $/ \mathrm{kg}$ oxidized a greater percent of the infused tyrosine, and incorporated a smaller percent into the tissue protein than animals infused at $0.5 \mathrm{mmole} / \mathrm{kg}$.

Muscle, liver, plasma, intestine, and kidney accumulated substantial amounts of radioactivity at both infusion levels. Determination of the radioactivity distribution between the free amino

Table 1. Plasma amino acid levels ( $\mu$ moles $/ d l)$ in rats undergoing total parenteral alimentation $(T P N)$ with and without added $L-$ alanylL-tyrosine ${ }^{1}$

\begin{tabular}{|c|c|c|c|c|c|c|}
\hline \multirow[b]{2}{*}{ Amino acid } & \multicolumn{2}{|c|}{ TPN without peptide } & \multicolumn{2}{|c|}{ TPN + 0.5 mmole peptide } & \multicolumn{2}{|c|}{ TFN +2 mmole peptide } \\
\hline & 0 time & $24 \mathrm{hr}$ & 0 time & $24 \mathrm{hr}$ & 0 time & $24 \mathrm{hr}$ \\
\hline Taurine & $12.8 \pm 4.27$ & $12.2 \pm 2.60$ & $10.6 \pm 4.46$ & $12.5 \pm 9.01$ & $9.81 \pm 1.56$ & $9.78 \pm 4.87$ \\
\hline Aspartate & $0.41 \pm 0.18$ & $0.42 \pm 0.22$ & $0.32 \pm 0.33$ & $0.63 \pm 0.22$ & $0.25 \pm 0.09$ & $0.64 \pm 0.40$ \\
\hline Threonine $^{2}$ & $16.6 \pm 2.78$ & $22.8 \pm 7.33$ & $15.4 \pm 2.65$ & $18.9 \pm 4.96$ & $16.6 \pm 1.98$ & $24.7 \pm 3.30$ \\
\hline Serine ${ }^{2}$ & $19.8 \pm 4.37$ & $27.3 \pm 6.71$ & $16.7 \pm 2.59$ & $25.0 \pm 6.48$ & $17.9 \pm 1.82$ & $21.7 \pm 2.00$ \\
\hline Glutamine-asparagine & $44.2 \pm 4.50$ & $40.1 \pm 2.16$ & $46.8 \pm 4.10$ & $41.1 \pm 4.21$ & $42.1 \pm 2.16$ & $39.1 \pm 2.00$ \\
\hline Glutamate & $4.57 \pm 1.78$ & $6.23 \pm 2.39$ & $4.46 \pm 1.71$ & $5.33 \pm 2.62$ & $4.66 \pm 1.00$ & $11.1 \pm 1.84$ \\
\hline Proline $^{2}$ & $12.7 \pm 0.95$ & $19.6 \pm 3.56$ & $13.8 \pm 1.55$ & $26.5 \pm 2.23$ & $13.5 \pm 2.56$ & $26.8 \pm 2.23$ \\
\hline Citrulline & $2.27 \pm 1.31$ & $2.11 \pm 1.16$ & $2.27 \pm 1.38$ & $3.10 \pm 2.73$ & $2.27 \pm 1.31$ & $2.11 \pm 1.16$ \\
\hline Glycine $^{2}$ & $30.1 \pm 17.1$ & $52.5 \pm 15.4$ & $27.1 \pm 4.17$ & $54.8 \pm 16.7$ & $23.8 \pm 4.01$ & $60.8 \pm 4.91$ \\
\hline Alanine ${ }^{2}$ & $23.8 \pm 4.81$ & $36.4 \pm 2.31$ & $25.2 \pm 3.48$ & $34.4 \pm 7.82$ & $23.7 \pm 2.89$ & $47.7 \pm 5.75$ \\
\hline Valine $^{2}$ & $16.8 \pm 2.82$ & $22.6 \pm 6.87$ & $12.8 \pm 2.55$ & $23.6 \pm 4.12$ & $17.5 \pm 2.17$ & $21.8 \pm 2.67$ \\
\hline $1 / 2-C y s t i n e$ & $8.10 \pm 2.45$ & $7.13 \pm 1.21$ & $8.42 \pm 2.06$ & $6.91 \pm 3.10$ & $8.78 \pm 2.17$ & $8.25 \pm 1.70$ \\
\hline Methionine ${ }^{2}$ & $6.24 \pm 1.22$ & $13.0 \pm 4.41$ & $5.61 \pm 1.92$ & $11.7 \pm 1.98$ & $7.57 \pm 3.89$ & $11.7 \pm 0.71$ \\
\hline Isoleucine $\mathrm{e}^{2}$ & $9.01 \pm 2.49$ & $12.3 \pm 5.58$ & $7.66 \pm 3.85$ & $11.9 \pm 4.32$ & $10.1 \pm 1.92$ & $12.8 \pm 2.98$ \\
\hline Leucine $^{2}$ & $15.6 \pm 3.78$ & $19.9 \pm 6.88$ & $13.9 \pm 4.29$ & $21.1 \pm 2.39$ & $13.8 \pm 0.70$ & $16.9 \pm 3.20$ \\
\hline Tyrosine & $7.69 \pm 1.32$ & $7.01 \pm 1.84$ & $7.24 \pm 1.81$ & $7.04 \pm 1.37$ & $6.31 \pm 0.68$ & $13.0 \pm 2.13$ \\
\hline Phenylalanine ${ }^{2}$ & $8.30 \pm 1.32$ & $12.6 \pm 2.88$ & $7.31 \pm 1.07$ & $11.4 \pm 2.07$ & $6.85 \pm 0.62$ & $10.1 \pm 1.28$ \\
\hline Ornithine & $4.18 \pm 0.60$ & $4.95 \pm 2.10$ & $4.05 \pm 0.42$ & $4.03 \pm 1.85$ & $4.63 \pm 0.78$ & $4.50 \pm 1.27$ \\
\hline Lysine $\mathrm{e}^{2}$ & $48.2 \pm 15.7$ & $67.8 \pm 16.7$ & $43.1 \pm 14.1$ & $57.1 \pm 14.8$ & $46.7 \pm 2.13$ & $65.8 \pm 17.8$ \\
\hline Histidine ${ }^{2}$ & $8.11 \pm 3.64$ & $11.1 \pm 4.95$ & $4.43 \pm 1.64$ & $8.51 \pm 1.31$ & $5.78 \pm 0.63$ & $8.51 \pm 1.22$ \\
\hline $\operatorname{Arginine}^{2}$ & $16.3 \pm 1.00$ & $21.7 \pm 4.92$ & $17.3 \pm 5.10$ & $20.9 \pm 1.84$ & $18.9 \pm 2.39$ & $24.5 \pm 4.56$ \\
\hline
\end{tabular}

' Data shown as mean \pm SD for the 5 animals studied in each group.

${ }^{2}$ Designates amino acids present in free form in TPN solution. 
Table 2. Radioactivity distribution after $24 \mathrm{hr}$ of total parenteral nutrition with $\mathrm{L}$-alanyl-L $-U-{ }^{14} \mathrm{C}$-tyrosine at 0.5 or $2.0 \mathrm{mmoles} / \mathrm{kg} / 24 \mathrm{hr}$

\begin{tabular}{|c|c|c|c|c|}
\hline Tissue & \multicolumn{2}{|c|}{ Infusion at $0.5 \mathrm{mmole} / \mathrm{kg}$} & \multicolumn{2}{|c|}{ Infusion at $2.0 \mathrm{mmole} / \mathrm{kg}$} \\
\hline Urine & $7.70 \pm 0.56$ & $73.7 \pm 13.7$ & $5.4 \pm 0.64$ & $55.1 \pm 12.7$ \\
\hline Liver & $7.08 \pm 2.52$ & $9.06 \pm 3.60$ & $4.50 \pm 0.52$ & $18.5 \pm 3.41$ \\
\hline Kidney & $1.43 \pm 0.37$ & $9.10 \pm 3.91$ & $1.05 \pm 0.29$ & $11.8 \pm 88.5$ \\
\hline Plasma & $4.01 \pm 0.94$ & $12.6 \pm 9.51$ & $6.11 \pm 0.98$ & $15.1 \pm 1.11$ \\
\hline Brain & $0.08 \pm 0.01$ & $\mathrm{NA}^{3}$ & $0.12 \pm 0.04$ & NA \\
\hline Stomach & $0.34 \pm 0.09$ & NA & $0.37 \pm 0.04$ & NA \\
\hline Heart & $0.13 \pm 0.02$ & NA & $0.20 \pm 0.05$ & NA \\
\hline Lung & $0.20 \pm 0.06$ & NA & $0.33 \pm 0.07$ & NA \\
\hline Spleen & $0.27 \pm 0.01$ & NA & $0.20 \pm 0.05$ & NA \\
\hline
\end{tabular}

'Data shown as mean \pm SD for five animals studied.

2 Value from two animals.

${ }^{3}$ Not analyzed.

acid fraction, protein bound fraction, and free alanyl-tyrosine of the various tissue fractions, showed $10-20 \%$ of the radioactivity present as free tyrosine, with the remainder in protein-bound form. Only trace quantities of radioactivity were detected at the L-alanyl-L-tyrosine position. The protein fraction from the various tissues contained $80-90 \%$ of the total activity. Isolation of tissue or plasma protein, followed by acid hydrolysis, and analysis for distribution of radioactivity among the various amino acids, demonstrated that $94-99 \%$ of the radioactivity present in the protein was tyrosine. These data demonstrate incorporation of labeled tyrosine into protein. Labeling did not result from conversion of tyrosine into nonessential amino acids with subsequent incorporation into protein.

Relatively little radioactivity was lost in the urine, and the percent of infused label appearing in the urine was similar at both peptide infusion levels. Animals infused at $0.5 \mathrm{mmole} / \mathrm{kg} /$ day excreted $7.7 \%$ of the label in the urine, (74\% was tyrosine and $26 \%$ alanyl-tyrosine). Animals infused at $2 \mathrm{mmoles} / \mathrm{kg} / \mathrm{day}$ excreted $5.4 \%$ of the label infused in the urine; $55 \%$ of the label appearing as tyrosine and $45 \%$ of the label eluting as alanyl-tyrosine (47).

Urinary tyrosine and alanine excretion were significantly higher $(P=0.001)$ in animals infused with parenteral solutions containing L-alanyl-L-tyrosine than in animals infused without peptide (Table 3 ). Animals infused at $0.5 \mathrm{mmole} / \mathrm{kg} / \mathrm{day}$ received a mean of 225 $\mu$ moles of peptide bound tyrosine and alanine daily. Urinary tyrosine excretion in these animals increased $10.3 \mu$ mole/day, and alanine excretion $9.4 \mu \mathrm{mole} /$ day above levels noted in control animals infused without peptide. This increase in tyrosine excretion occurred despite plasma tyrosine levels which were unchanged from fasting levels (Table 1) and which were identical to those observed in control animals. Animals infused with I-alanyl$\mathrm{L}$-tyrosine at $2 \mathrm{mmole} / \mathrm{kg} /$ day received a mean of $800 \mu$ moles of peptide bound tyrosine and alanine daily. Urinary tyrosine excretion in these animals increased by $20 \mu$ mole/day and alanine levels increased $23 \mu \mathrm{mole} /$ day above levels noted in control animals infused without peptide.

The data in Table 4 show the effect of the parenteral feeding regimens upon erythrocyte free amino acid levels. Changes in erythrocyte levels of free amino acids during the infusion periods were similar to those observed in plasma (Table 1). Erythrocyte alanine and tyrosine levels were significantly higher in animals infused with the solution providing alanyl-tyrosine at $2 \mathrm{mmole} /$ $\mathrm{kg} /$ day than in animals infused with the tyrosine-free solution, indicating utilization of the peptide to supply erythrocyte tyrosine pools.
The data in Table 5 suggest that infusion of alanyl-tyrosine at $2.0 \mathrm{mmole} / \mathrm{kg} /$ day helps maintain tyrosine levels in certain tissues at values seen in orally fed control animals, in contrast to animals fed parenterally without a tyrosine source. Liver and kidney tyrosine levels were lower in parenterally fed animals receiving either the tyrosine-free base solution, or the base solution containing 0.5 mmoles peptide $/ \mathrm{kg} /$ day than in orally fed control animals. Liver and kidney tyrosine levels in animals infused with 2.0 mmoles peptide $/ \mathrm{kg} /$ day were similar to those seen in orally fed control animals. Tissue alanine levels showed few differences between experimental groups, although liver alanine levels were significantly higher in animals infused with alanyl-tyrosine at 2.0 $\mathrm{mmole} / \mathrm{kg} / \mathrm{day}$.

These data indicate good utilization of alanyl-tyrosine as a parenteral tyrosine source for protein synthesis and suggest that the infusion of adequate alanyl-tyrosine maintains plasma, erythrocyte, and tissue tyrosine pools in parenterally fed animals.

\section{DISCUSSION}

The evidence for metabolic utilization of tyrosine when administered as alanyl-tyrosine is strong and consists of three elements. First, $40-50 \%$ of the radioactivity administered appears as ${ }^{14} \mathrm{C}$ carbon dioxide, when peptide was administered as part of the parenteral regimen at either 0.5 or $2.0 \mathrm{mmole} / \mathrm{kg} / \mathrm{day}$. This clearly indicates hydrolysis of the peptide and oxidation of the tyrosine. Second, the increased plasma and tissue tyrosine levels during infusion at $2.0 \mathrm{mmole} / \mathrm{kg} / \mathrm{day}$, and the presence of radioactivity as tyrosine in the free amino acid pools of both plasma and tissues indicates its availability. Finally, and most importantly, from the perspective of growth and tissue repair, radioactive tyrosine was incorporated into both plasma and tissue proteins as tyrosine, and protein-bound tyrosine accounted for $80-90 \%$ of the radioactivity found in these tissues. The data demonstrate that tyrosine from alanyl-tyrosine is rapidly metabolized when administered as part of a parenteral alimentation solution and provides free tyrosine for energy substrate, tissue tyrosine pools, and protein synthesis. Urinary losses are small (5-8\%). These results indicate L-alanyl-Ltyrosine serves as a tyrosine source for the rat during iv feeding.

Snyderman (33) has presented evidence that tyrosine is an essential amino acid for some premature infants even in the presence of adequate phenylalanine intake. She has estimated the tyrosine requirements for such orally fed infants to be $50-120 \mathrm{mg} /$ $\mathrm{kg}$ /day $(32,33)$. Extrapolation of her oral feeding data to parenteral alimentation suggests the need for $50-120 \mathrm{mg}(0.3-0.66$ 
Table 3. Urinary amino acid excretion ( $\mu$ mole/24 hr) in rats undergoing total parenteral alimentation (TPN) with and without added L. alanyl-L-tyrosine at 0.5 or $2.0 \mathrm{mmole} / \mathrm{kg}^{1}$

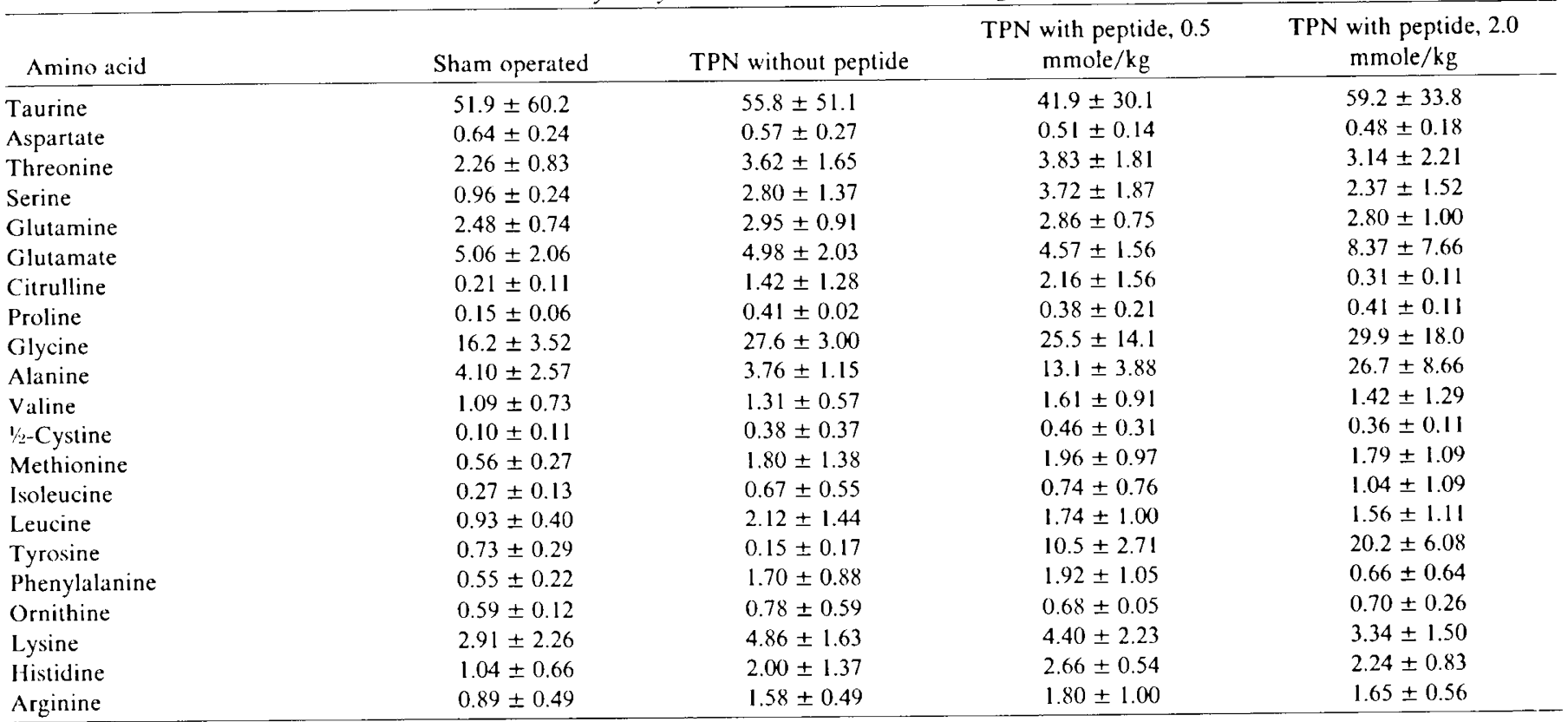

'Data shown as mean \pm SD for the five animals studied in each group.

Table 4. Erythrocyte free amino acid levels (umole $/ 100 \mathrm{~g}$ cells) ${ }^{1}$

\begin{tabular}{|c|c|c|c|c|c|c|}
\hline \multirow[b]{2}{*}{ Amino acid } & \multicolumn{2}{|c|}{ TPN infused animals } & \multicolumn{2}{|c|}{ TPN animals $+0.5 \mathrm{~mm}$ peptide } & \multicolumn{2}{|c|}{ TPN infused +2.0 mmole peptide } \\
\hline & 0 time & $24 \mathrm{hr}$ & 0 time & $24 \mathrm{hr}$ & 0 time & $24 \mathrm{hr}$ \\
\hline Taurine & $26.4 \pm 6.43$ & $34.5 \pm 9.18$ & $37.2 \pm 13.4$ & $18.9 \pm 12.9$ & $\mathrm{t} 35.8 \pm 8.21$ & $40.3 \pm 19.1$ \\
\hline Aspartate & $0.51 \pm 0.21$ & $0.70 \pm 0.21$ & $0.49 \pm 0.36$ & $0.52 \pm 0.46$ & $1.23 \pm 0.40$ & $1.46 \pm 0.82$ \\
\hline Threonine ${ }^{2}$ & $12.4 \pm 2.54$ & $15.5 \pm 6.11$ & $9.20 \pm 2.24$ & $13.8 \pm 3.37$ & $11.8 \pm 0.20$ & $15.2 \pm 2.59$ \\
\hline Serine $^{2}$ & $17.1 \pm 1.81$ & $22.7 \pm 6.60$ & $16.4 \pm 4.91$ & $21.7 \pm 4.01$ & $15.5 \pm 1.21$ & $25.1 \pm 6.17$ \\
\hline Glutamine-asparagine & $33.1 \pm 1.95$ & $28.7 \pm 4.12$ & $30.7 \pm 2.61$ & $28.6 \pm 4.21$ & $30.0 \pm 1.98$ & $28.9 \pm 2.16$ \\
\hline Glutamate & $22.7 \pm 4.10$ & $21.0 \pm 5.51$ & $21.9 \pm 7.50$ & $17.6 \pm 3.08$ & $26.6 \pm 4.71$ & $28.1 \pm 1.51$ \\
\hline Proline ${ }^{2}$ & $15.6 \pm 2.16$ & $28.1 \pm 8.71$ & $16.0 \pm 1.61$ & $28.4 \pm 1.61$ & $14.8 \pm 4.10$ & $30.1 \pm 5.50$ \\
\hline Glycine $^{2}$ & $21.9 \pm 4.12$ & $42.4 \pm 10.4$ & $29.4 \pm 7.75$ & $45.9 \pm 10.4$ & $22.5 \pm 3.11$ & $48.0 \pm 4.41$ \\
\hline Alanine & $26.6 \pm 4.34$ & $28.6 \pm 7.12$ & $29.3 \pm 6.31$ & $26.8 \pm 5.84$ & $19.2 \pm 1.21$ & $35.1 \pm 6.00$ \\
\hline Valine & $12.5 \pm 2.55$ & $17.3 \pm 8.84$ & $10.2 \pm 3.75$ & $11.6 \pm 2.34$ & $11.5 \pm 1.71$ & $15.4 \pm 1.54$ \\
\hline Methionine ${ }^{2}$ & $4.91 \pm 1.32$ & $9.87 \pm 4.72$ & $4.26 \pm 0.72$ & $7.18 \pm 1.57$ & $4.09 \pm 0.96$ & $8.30 \pm 0.60$ \\
\hline Isoleucine $\mathrm{e}^{2}$ & $6.16 \pm 1.88$ & $9.17 \pm 4.25$ & $5.50 \pm 2.85$ & $6.90 \pm 2.07$ & $13.2 \pm 0.91$ & $19.0 \pm 5.80$ \\
\hline Leucine $^{2}$ & $11.1 \pm 2.63$ & $15.2 \pm 3.91$ & $9.00 \pm 3.90$ & $10.6 \pm 1.50$ & $10.3 \pm 1.43$ & $12.9 \pm 3.66$ \\
\hline Tyrosine & $7.09 \pm 0.74$ & $6.87 \pm 2.48$ & $7.67 \pm 2.68$ & $6.80 \pm 1.18$ & $5.38 \pm 0.53$ & $11.7 \pm 0.41$ \\
\hline Phenylalanine & $6.73 \pm 1.33$ & $11.4 \pm 3.82$ & $6.35 \pm 1.30$ & $8.63 \pm 0.64$ & $5.06 \pm 0.71$ & $8.40 \pm 0.10$ \\
\hline Ornithine & $4.86 \pm 0.89$ & $4.71 \pm 0.95$ & $3.19 \pm 0.73$ & $3.40 \pm 0.39$ & $6.20 \pm 1.00$ & $4.03 \pm 0.30$ \\
\hline Lysine $^{2}$ & $62.1 \pm 14.9$ & $54.4 \pm 12.6$ & $62.7 \pm 12.5$ & $60.1 \pm 12.7$ & $52.5 \pm 6.40$ & $66.6 \pm 8.53$ \\
\hline Histidine ${ }^{2}$ & $5.87 \pm 2.39$ & $8.46 \pm 1.74$ & $4.64 \pm 0.84$ & $6.02 \pm 1.12$ & $4.55 \pm 0.72$ & $5.79 \pm 0.74$ \\
\hline Arginine ${ }^{2}$ & $33.1 \pm 8.70$ & $36.8 \pm 8.87$ & $32.6 \pm 8.88$ & $37.6 \pm 8.85$ & $39.1 \pm 6.66$ & $40.1 \pm 7.65$ \\
\hline
\end{tabular}

' Data shown as mean \pm SD for five animals studied in each group.

"Amino acids present in parenteral solution.

mmole) of tyrosine per $100 \mathrm{ml}$ of solution, assuming an infusion rate of $100-120 \mathrm{ml} / \mathrm{kg} / 24 \mathrm{hr}$ of a standard parenteral solution of $2.5 \%$ amino acids- $25 \%$ glucose. Alanyl-tyrosine has a solubility of approximately $22 \mathrm{mmole} / 100 \mathrm{ml}(36)$. This solubility may permit development of the peptide as an additive for iv solutions in a manner similar to that currently used for electrolytes. This would eliminate the need for its presence in the amino acid mixture fed all infants.

Some studies have suggested that peptides, such as those found in protein hydrolysate solutions, are not well utilized during iv infusion $(7-11,13,16,21,23)$. However, peptide fractions of protein hydrolysates are well utilized during iv administration in infants and adults in Maillard condensation products are excluded from the solution $(11,36,39)$. The present data support that hypothesis, show good utilization of infused peptide, and agree with data of Adibi and colleagues $(2,3)$ who reported rapid metabolism of single doses of glycyl-glycine and glycyl-leucine injected into the jugular vein of rats. Although these studies with L-alanyl-L-tyrosine are restricted to adult animals, the authors believe that the neonate will also utilize the peptide. Human infants metabolize peptides present in protein hydrolysates administered parenterally $(36,39)$.

With the exception of tyrosine and alanine, plasma levels of amino acids were similar in all groups of parenterally fed rats after $24 \mathrm{hr}$ infusion. Plasma levels of those amino acids present in free form in the parenteral solution increased from fasting levels to those considered postprandial, while levels of those amino acids not present were generally unchanged or decreased. Plasma ala- 
Table 5. Tissue tyrosine and alanine levels in rats undergoing total parenteral nutrition $(T P N)$ with and without added $L$. alanyl-L-tyrosine at 0.5 and $2 \mathrm{mmol} / \mathrm{kg} / 24 \mathrm{hr}^{1}$

\begin{tabular}{ccc}
\hline Tissue & $\begin{array}{c}\text { Alanine } \\
\mu \text { mole/g tissue (wet wt) }\end{array}$ \\
\hline
\end{tabular}

Intestine

Operated but oral fed

TPN (no peptide)

TPN (0.5 mmole $/ \mathrm{kg}$ alanine-tyrosine)

$0.93 \pm 0.12$

$0.53 \pm 0.06$

$0.91 \pm 0.30 \quad 0.34 \pm 0.10^{2}$

TPN (2.0 mmole/ $\mathrm{kg}$ alanine-tyrosine)

$0.80 \pm 0.13$

$0.33 \pm 0.11^{2}$

$0.91 \pm 0.22 \quad 0.40 \pm 0.12^{3}$

Muscle

Operated but oral fed

$0.70 \pm 0.20$

$0.10 \pm 0.03$

TPN (no peptide)

$0.88 \pm 0.27$

$0.09 \pm 0.03$

$0.74 \pm 0.20 \quad 0.09 \pm 0.03$

$0.75 \pm 0.14$

$0.12 \pm 0.04$

Kidney

Operated but oral fed

TPN (no peptide)

TPN (0.5 mmole $/ \mathrm{kg}$ alanine-tyrosine)

$0.82 \pm 0.15$

$0.35 \pm 0.07$

$0.81 \pm 0.21$

$0.75 \pm 0.11$

$0.19 \pm 0.06^{2}$

$0.16 \pm 0.07^{2}$

$0.96 \pm 0.40 \quad 0.38 \pm 0.11$

Liver

$\begin{array}{lll}\text { Operated but oral fed } & 1.48 \pm 0.67 & 0.15 \pm 0.04 \\ \text { TPN (no peptide) } & 1.75 \pm 0.60 & 0.08 \pm 0.03^{2} \\ \text { TPN }(0.5 \mathrm{mmole} / \mathrm{kg} \text { alanine-tyrosine }) & 1.63 \pm 0.54 & 0.07 \pm 0.03^{2} \\ \text { TPN }(2.0 \mathrm{mmole} / \mathrm{kg} \text { alanine-tyrosine) } & 2.45 \pm 0.56^{3} & 0.14 \pm 0.04\end{array}$

' Data shown as mean \pm SD.

2 Differ significantly from oral fed control animals, $P=0.01$.

${ }^{3}$ Differ significantly from oral fed control animals, $p=0.05$.

nine and tyrosine levels were similar in control animals infused with the tyrosine-free solution parenteral solution and those infused with the identical solution with 0.5 mmoles alanyl-tyrosine/ $\mathrm{kg} /$ day. This suggests rapid metabolism of the peptide at this infusion level by the tissues without affecting tissue plasma amino acid pools. Infusion of the solution containing sufficient peptide to provide $2.0 \mathrm{mmole} / \mathrm{kg}$ significantly increased plasma alanine and tyrosine levels, indicating hydrolysis in tissues with subsequent exchange in plasma. Rat plasma contains a small amount of peptidase activity towards alanyl-tyrosine. However, this level could not account for the rapid disappearance of peptide from the blood, indicating uptake of peptide into the tissue with subsequent intracellular hydrolysis. Adibi et al. $(2,3)$ reached a similar conclusion in their studies of glycyl-glycine and glycyl-leucine.

The data from this study suggest that infusion of alanyl-tyrosine at $2.0 \mathrm{mmole} / \mathrm{kg} /$ day helps to maintain tissue tyrosine levels in parenterally fed rats. Muscle, liver, intestine, and kidney free amino acid levels were determined, because these tissues contain large amounts of radioactivity after infusion of the radioactive peptide (Table 2). In general, tissue levels of amino acids were similar to those reported by Adibi et al. (1). However, rats fed parenterally without a tyrosine source had lower liver, kidney, and intestinal tyrosine levels than orally fed control animals. Although the addition of alanyl-tyrosine to the solution at 0.5 mmole $/ \mathrm{kg} /$ day had little effect upon tyrosine levels in these tissues, the addition of $2.0 \mathrm{mmoles}$ peptide $/ \mathrm{kg} / \mathrm{day}$ resulted in tissue tyrosine levels close to those noted in orally fed control animals. Tyrosine levels in muscle showed no significant changes between experimental groups, in keeping with other reports suggesting that muscle amino acid levels are relatively unaffected by changes in plasma levels $(5,12,18,20,42,43)$.

The parenteral solution contains adequate free alanine, and few changes in tissue alanine levels were noted. However, liver alanine levels were increased in animals infused with alanyl-tyrosine at $2.0 \mathrm{mmole} / \mathrm{kg}$, suggesting rapid uptake of peptide by the liver.

Urinary tyrosine and alanine excretion was increased in animals infused with parenteral solutions containing alanyl-tyrosine when compared to animals infused with the same solution without peptide. The increased urinary losses of tyrosine and alanine were not due to an "overflow" aminoaciduria in animals infused at 0.5 mmoles peptide $/ \mathrm{kg} /$ day because plasma tyrosine and alanine levels did not differ from those noted in control animals infused without peptide. The slightly increased total urinary losses of tyrosine and alanine noted in animals infused at $2.0 \mathrm{mmole} / \mathrm{kg} /$ day may reflect the slightly increased plasma levels in these animals. The data suggest that the peptide entering the glomerular filtrate is hydrolyzed by peptidases on the mucosal surface of renal epithelial cells without efficient reabsorption. This results in the urinary excretion of both the peptide and its constituent amino acids.

A relatively small percent of the tyrosine infused as peptide was lost in the urine. Radioactivity measurements (Table 2) show a loss of $7.7 \%$ of the tyrosine present in the infused peptide in animals infused at $0.5 \mathrm{mmole} / \mathrm{kg} / \mathrm{day}$, with a $5.4 \%$ loss noted in animals infused at $2.0 \mathrm{mmole} / \mathrm{kg} / \mathrm{day}$. This level of peptide loss is similar to that reported by Christensen et al. (11). for adult men infused with protein hydrolysate solutions and that reported for infants fed parenterally with protein hydrolysate-based solutions (39).

In summary, the data presented indicate rapid metabolism of iv administered alanyl-tyrosine, showing that utilization of this peptide as an amino acid source does not first require passage through the gastrointestinal tract or liver. Only minimal loss of infused tyrosine from the peptide occurs in the urine. These data suggest rapid intake and metabolism of the peptide by a large number of tissues in the rat.

\section{REFERENCES AND NOTES}

1. Adibi, S. A.: Interrelationship between level of amino acids in plasma and tissues during starvation. Am. J. Physiol., 221: 829 (1971).

2. Adibi, S. A., and Krzysik. B. A.: Effect of nephrectomy and enterectomy on plasma clearance of intravenously administered dipeptides in rats. Clin. Sci. Mol. Med., 52: 205 (1977).

3. Adibi, S. A., Krzysik, B. A., and Drash, A.: Metabolism of intravenously administered dipeptides in rats: effects on amino acid pools, glucose concentration and insulin and glucagon secretion. Clin. Sci. Mol. Med., 52: 193 (1977).

4. Avery, M. E., Clow, C. L., Menkes, J. H., Ramos, A., Scriver, C. R., Stern, L. and Wasserman. B. P.: Transient tyrosinemia of the newborn: Dietary and clinical aspects. Pediatric, 39: 378 (1967).

5. Bergström, J., Fürst, P., Noree, L. O., and Vinnars, E.: Intracellular free amino acid concentration in human muscle tissue. J. Appl. Physiol., 36: 693 (1974).

6. Bray, G. A.: A simple efficient liquid scintillator for counting aqueous solutions in a liquid scintillation counter. Anal. Biochem., $I: 279$ (1960).

7. Christensen, H. N.: Peptide wastage consequent to the infusion of two protein hydrolysates. J. Nutr., 42: 189 (1950).

8. Christensen, H. N., Lynch, E. L. and Powers, J. H.: The conjugated, nonprotein, amino acids of plasma. III. Peptidemia and hyperpeptiduria as a result of the intravenous administration of partially hydrolysed casein (amigen). J. Biol. Chem., 166: 649 (1946).

9. Christensen, H. N., Lynch, E. L., Decker, D. G., and Powers, J. H.: The conjugated, non-protein amino acids of plasma. IV. A difference in the utilization of hydrolysates of fibrin and casein. J. Clin. Invest., 26: 849 (1947).

10. Christensen, H. N., Lynch, E. L. and Powers, J. H.: The conjugated, non-protein, amino acids of plasma. V. A study of the clinical significance of peptidemia. J. Clin. Invest., 26: 853 (1947)

11. Christensen, H. N., Wilber, P. B., Coyne, B. A. and Fisher, J. H.: Effects of simultaneous or prior infusion of sugars on the fate of infused protein hydrolysates. J. Clin. Invest., 34: 86 (1955).

12. Christophe, J., Winand, J., Kutzner, R. and Hebbelinck, M.: Amino acid levels in plasma, liver, muscle and kidney during and after exercise in fasted and fed rats. Am. J. Physiol., 221: 453 (1971).

13. Cox. W. M., Jr. and Mueller, A. J.: The relative efficiency of different forms of intravenously administered nitrogen on nitrogen balance and amino acid excretion. J. Nutr., 3I: 581 (1946).

14. Dickinson, J. C., Rosenblum, H. and Hamilton, P. B.: Ion-exchange chromatography of free amino acids in the plasma of the newborn infant. Pediatrics, 36: 2 (1965).

15. Efron. M. L.: Quantitative estimation of amino acids in physiological fluids using a Technicon amino acid analyzer. In: L. T. Skeggs; Automation In Analytical Chemistry, p. 637 (Mediad Inc., New York, 1966).

16. Elman. R.: Partial replacement of protein with the amino acids of hydrolyzed casein. Ann. Surg., 112: 594 (1940).

17. Filer, L. J., Jr., Stegink, L. D., and Chandramouli, B.: Effects of diet on plasma aminograms of low-birth-weight infants. Am. J. Clin. Nutr., 30: 1036 (1977).

18. Fürst, P., Bergström, J., Ahlberg, M., and Noree, L. O.: The nutritional benefits of essential amino acid supplementation of low protein diets in chronic renal failure. Zeitschrift für Ernahrungswissenschaft, (Suppl.) 19: 13 (1977). 
19. Gaull, G. Sturman, J. A., and Raiha, N. C. R.: Development of mammalian sulfur metabolism. Absence of cystathionase in human fetal tissues. Pediatr. Res., o: 538 (1972)

20. Herbert, J. D., Coulson, R. A., and Hernandez. T.: Free amino acids in the caiman and rat. Comp. Biochem. Physiol., 17: 583 (1966).

21. Jonxis, J. H. P., and Huisman. T. H. J.: Excretion of amino acids in free and bound form during intravenous administration of protein hydrolysate. Metabolism, 6: 175 (1957).

22. Levy, H. L.. Shih, V. E., Madigan, P. M., and MacCready, R. A.: Transient tyrosinemia in full term infants. J.A.M.A., 209: 249 (1969)

23. Long. C. L.. Zikria, B. A., Kinney, J. M., and Geiger, J. W.: Comparison of lirbin hydrolysates and crystalline amino acid solutions in parenteral nutrition. Am. J. Clin. Nutr. 27: 163 (1974).

24. Mamunes, P., Prince, P. E., Thornton, N. H., Hunt, P. A., and Hitchcock, E. S.: Intellectual deficits after transient tyrosinemia in the term neonate. Pediatric. 57: 675 (1976)

25. Menkes, J. H., Chernick, V., and Ringel, B.: Effect of elevated tyrosine on subsequent intellectual development of premature infants. J. Pediatr., 69: 583 (1966).

26. Menkes, J. H., Welcher. D. W., Levi, H. S., Dallas, J., and Gretsky, N. E. Relationship of elevated blood tyrosine to the ultimate intellectual performance of premature infants. Pediatrics, 49: 218 (1972).

27. Palese, M. and Tephly, T. R. Metabolism of formate in the rat. J. Toxicol Environ. Health. 1: 13 (1975).

28. Partington, M. W., Delahaye, D. J., Masotti, R. E., Read, J. H., and Roberts, B.: Neonatal tyrosinemia: A follow-up study. Arch. Dis. Child., 43: 195 (1968).

29. Perry, T. L., and Hansen, S.: Technical pitfalls leading to errors in the quantitation of plasma amino acids. Clin. Chim. Acta, 25: 53 (1969).

30. Pohlandt, F.: Cystine: a semi-essential amino acid in the newborn infant. Acti Paediatr. Scand., 63: 801 (1974).

31. Popovic, V., and Popovic, P.: Permanent cannulation of aorta and vena cava in rats and ground squirrels. J. Appl. Physiol., 15: 727 (1960).

32. Snyderman, S. E.: Recommendations for parenteral amino acid requirements In: R. W. Winters and E. G. Hasselmeyer: Intravenous Nutrition In the High Risk Infant. p. 422 (John Wiley and Sons, New York, 1975).

33. Snyderman, S. E.: The protein requirements of the premature infant. In: J. H. P. Jonxis, H. K. A. Visser, and J. A. Troelstra: Nutricia Symposium. Metabolic Processes In the Foetus and Newborn Infant. p. $128-143$ (Stenfert Kruesse. Leiden, 1971)

34. Steel, R. G., and Torrie, J. W.: In: Principles and Procedures of Statistics. p. 49 66 (McGraw Hill, New York, 1960).

35. Stegink, L. D.: Amino acid metabolism. In: R. W. Winters and E. G. Hasselmeyer:
Intravenous Nutrition In The High Risk Infant. p. 181 (John Wiley and Sons, New York, 1975).

36. Stegink, L. D.: Peptides in parenteral nutrition. In: H. L. Green, M. A. Holliday, and H. N. Munro: Clinical Nutrition Update: Amino Acids p. 192-19 (American Medica! Association, Chicago, 1977).

37. Stegink, L. D.: Simultaneous measurement of radioactivity and amino acid composition in physiological fluids during amino acid toxicity studies. In Advances in Automated Analysis. Vol. I p. 591 (Halos Association, Miami, 1970)

38. Stegink, L. D., and Baker, G. L.: Infusion of protein hydrolysates in the newborn infant: Plasma amino acid concentrations. J. Pediatr., 78: 595 (1971).

39. Stegink, L. D., Shepherd, J. A., Fry, L. K., and Filer, L. J., Jr. Sugar-amino acid complexes in parenteral alimentation. Pediatr. Res., 8: 386 (1974).

40. Steiger, E., Vars, H. M., and Dudrick, S. J. A technique for longterm intravenous feeding in unrestrained rats. Arch. Surg., 104: 330 (1972).

41. Sturman, J. A Gaull, G., and Raiha, N C R.: Absence of cystathionase in human fetal liver. Is cystine essential? Science, 169: 74 (1970).

42. Vinnars, E., Bergström, J., and Fürst, P.: Influence of the post operative state on the intracellular free amino acids in human muscle tissue. Ann. Surg., 182: 665 (1975).

43. Vinnars, E., Fürst. P., Bergström, J., and von Francken, I.: Intracellular free amino acids in muscle tissue in normal man and in different clinical conditions. In: A. W. Wilkinson and D. Cuthbertson: Metabolism and the Response to Injury. p. 336-350 (Pitman Medical Publish. Co., London, 1976).

44. Warner, R. G.: Nutrient requirements of the laboratory rat. In: Nutrient requirements of Domestic Animals. Laboratory Animals. Publication 990 p. 56 (National Academy of Sciences-National Research Council, Washington. 1952).

45. Wong. P. W. K., Lambert, A. M., and Komrower. G. M.: Tyrosinemia and tyrosyluria in infancy. Devel. Med. Child. Neurol., 9: 551 (1967).

46. The present address of Dr. Tahia. T. Daabees is: Department of Pharmacology, Faculty of Pharmacy, Alexandria University, Egypt.

47. Alanyl-tyrosine elutes at the hydroxylysine position of the sodium buffer system of the Beckman $121 \mathrm{M}$ amino acid analyzer, and just prior to ammonia on the Technicon $\mathrm{NCl}$ analyzer using the Efron buffer system (15).

48. Requests for reprints should be addressed to: Dr. Lewis D. Stegink, Department of Pediatrics. S-265 Hospital School. The University of Iowa, Iowa City, lowa 52242, USA.

49. This research was supported in part, by a grant-in-aid from the National Foundation - March of Dimes.

50. Received for publication April 4, 1978.

51. Accepted for publication July 27, 1978 . 